\title{
A re-evaluation of the Feldstein-Horioka puzzle in the Eurozone
}

\author{
Vasilios Plakandaras ${ }^{1}$, Periklis Gogas ${ }^{1}$ and Theophilos Papadimitriou ${ }^{1}$
}

\begin{abstract}
In this paper we re-evaluate the capital immobility hypothesis of Feldstein and Horioka (1980) for the case of the European Union and the Eurozone, based on long-run regressions. We employ the Long Run Derivative proposed by Fischer and Seater (1993) in order to examine capital mobility as a longrun phenomenon. In order to enhance the robustness of our results we also perform panel causality tests on our data as it is a common approach in this setting. Our empirical findings provide no evidence in favor of the capital immobility hypothesis. In fact, we reject capital immobility even before the creation of the European Union, the introduction of the Eurozone or the 2008 global financial crisis.
\end{abstract}

JEL Classification numbers: F20, F30

Keywords: Feldstein -Horioka puzzle, Investment, Savings, International Economics

\section{Introduction}

The Maastricht treaty was the cornerstone in the integration process within the European Union countries. Among the many ramifications for the participating country-members the most important was the creation of a single market where the mobility of capital was supposed to be free of custom procedures, import tariffs and quotas, legal obstacles or tax impediments. Free capital mobility was expected to increase optimization of resource allocation within the EU, increase capital returns and ultimately accelerate the economic convergence between member-states. In fact, the treaty went a step further with the creation of a common currency that would eliminate exchange rate risk and enhance trade within the common European market. Nevertheless, the current empirical research reveals that free capital mobility within the common EU market has never been completely achieved.

A common approach in testing free capital mobility in the international economics literature is the work of Feldstein and Horioka (1980). The authors state that the coefficient from the regression of investment on savings is an indicator of capital mobility freedom, arguing that values close to zero indicate a state of capital mobility with no barriers, since changes on savings do not affect investment decisions. In other words, given the existence of complete capital mobility, any household is free to seek for an investment in the international market that maximizes returns on its invested capital, instead of selecting domestic saving. A coefficient close to unity provides evidence in support of no capital mobility. The authors regress the ratio of investment to GDP on the ratio of savings to GDP in a sample of 16 OECD countries spanning the period 1960-1974, based on cross-country examination. Their empirical findings suggest that the coefficient of investment to savings in close to one, i.e. lies between 0.85 to 0.95 .

\footnotetext{
${ }^{1}$ Democritus University of Thrace, Department of Economics, Greece
} 
Despite the criticism raised by Krugman (1991) that it is the current account deficits that differentiate savings and investment and not capital mobility openness, the relationship examined by Feldstein and Horioka ( $\mathrm{F}-\mathrm{H}$ hereafter) has been among one of the most heavily researched and cited issues in international economics. In fact, Obstfeld and Rogoff (2001) include the F-H relationship among the six unanswered paradoxes (puzzles) in international economics and state that the F-H puzzle is caused by trade frictions. The related empirical research provides evidence both in favor and against the F-H puzzle spanning a variety of methodologies, time periods, countries examined and econometric setup. Many authors attempt to provide an explanation of why the F-H paradox still holds in the latest decades, regardless of the World Trade Organization agreements for the liberalization of trade, the creation of free trading zones around the globe and the free floating era in exchange rates that are expected to enhance capital mobility ${ }^{2}$.

Focusing on the European Monetary Union (EMU) and the EU common market, Blanchard and Giavazzi (2002) study current account balances, savings and investment for 15 OECD countries spanning the period 1975-2001. The authors find that a decreased private savings and an increased investment ratio of GDP are the main drivers for the increased deficits of the poorest EMU and EU members such as Greece and Portugal for the period. With the use of panel regressions Blanchard and Giavazzi (2002) conclude that the F-H puzzle cannot be detected in the post 1993 period and that free capital mobility and positive growth perspectives for the poorest EMU and EU countries will lead to smaller future account balance deficits through large capital inflows towards the European south, a projection not verified by the recent sovereign crises among the southern EU countries.

Telatar et al. (2007) revisit the F-H relationship using country-specific Markov regime switching models of savings and investment for nine EU countries spanning the period 1970-2002. Despite that their models are restricted in country level abolishing cross-country relationships, they detect that most European countries moved from a low to a high capital mobility regime after the creation of the EMU with the exception of Germany, Netherlands and the UK. Remaining in a country specific examination, Serletis and Gogas (2007) apply long-horizon regressions tests in the econometric framework of the Long Run Derivative (LRD) proposition, originally developed by Fisher and Seater (1993) to test for the long-run neutrality of money. Using annual time series spanning the period 1960-2002 for 15 EU countries and the U.S. and Japan, the authors find empirical evidence against the existence of low capital mobility in the long-run. Supportive evidence for a negative EMU effect on the saving retention coefficient has also been found by Kumar and Rao (2011) in a sample of 13 OECD countries. Using the Pedroni panel cointegration technique for investment and saving, they find that capital mobility has increased in the post Bretton Woods and Maastricht period.

Choudhry et al. (2014) extend the panel estimation procedure of F-H in 252 OECD countries for the period 1990-2012, adding dummy variables for the EMU countries and alternative aggregates of savings and investment. They find that capital mobility between markets increased until the start of the global 2008 financial crisis, followed by a significant decline afterwards. However, the source of the post-2008 disintegration in the EU countries is not detected. Johnson and Lamdin (2014) also find a positive impact of the financial crisis on the coefficient of the saving ratio for the countries of the EU, examining a sample of 40 OECD countries for the 1980-2012 period. For the rest of the countries the savings ratio coefficient remains unaffected.

Katsimi and Zoega (2016) apply the differences-in-differences method to study the F-H equation with countries outside the single market serving as a control group and those within as a treatment group. The results suggest that the correlation between investment and savings depends on the structure of EU institutions, the exchange rate risk and the credit risk, while structural breaks coincide with the creation of the EU and the EMU, in addition to the financial crisis in 2008. Furthermore, the pattern of

\footnotetext{
${ }^{2}$ The disposition of the entire literature on the F-H puzzle is beyond the scope of this paper, since we are more interested in studies on the EU and the EMU. The interested reader could refer to Apergis and Tsoumas (2009) for the most common survey on the F-H puzzle.
} 
capital flows within the single market leaves a significant part of the flows unexplained by fundamentals. Under a different perspective, Smitz and von Hagen (2011) study the relationship between trade balances and per-capita incomes using panel estimation on a sample of EU-15 countries over the time period 1981-2005. The authors go as far as stating that current account imbalances between EU members are a measure of capital flows. The empirical findings corroborate previous studies on the integration of the Eurozone countries after the introduction of the common currency, since on an aggregate level the euro area trade account appears balanced, suggesting high capital mobility. Overall, the empirical findings of the related literature on capital mobility between European countries suggest that after the introduction of the common market and the common currency capital mobility has risen. Nevertheless, the recent global financial crisis has decelerated the integration process, introducing trade barriers and lowering capital mobility.

In this paper we re-examine and extend the findings of Serletis and Gogas (2007) in the light of the current financial crisis. Since their analysis ends at 2002 before the wide introduction of the euro currency, we move one step further and include both the effects of the creation of the Eurozone and of the recent financial crisis in our long-run regressions. By doing so, we compare regressions of investment to savings and vice versa. We find that the creation of the EU common market and of the Eurozone have not altered significantly the capital mobility rate between the EU countries. Moreover, the relationship between investment and savings is not unilateral. The same findings stands for the U.S. and Japan. In contrast, the 2008 financial crisis lead to a decrease in capital mobility. In order to enhance the robustness of our long-run regression findings, we repeat our analysis based on panel estimation. Overall, we do not find evidence in favor of the F-H hypothesis, accepting that the trade relationships between the EU countries are strong throughout the examined period.

\section{Long run derivative}

Fisher and Seater (1993) propose the following bivariate autoregressive representation

$$
\begin{aligned}
& a_{i i}(L) \Delta^{\langle i\rangle} i_{t}=a_{i s}(L) \Delta^{\langle s\rangle} s_{t}+\varepsilon_{t}^{i} \\
& a_{s s}(L) \Delta^{\langle s\rangle} s_{t}=a_{s i}(L) \Delta^{\langle i\rangle} s_{t}+\varepsilon_{t}^{S}
\end{aligned}
$$

where $a_{i i}^{0}=a_{s s}^{0}=1, \Delta=1-L, L$ is the lag operator, $i$ is the investment share of output, $s$ is the saving share of output and $\langle z\rangle$ is the order of integration of $z$, thus $\langle\Delta z\rangle=\langle z\rangle-1$. The vector of residuals $\left(\varepsilon_{t}^{i}, \varepsilon_{t}^{S}\right)^{\prime}$ is assumed to be i.i.d. with mean zero and covariance $\Sigma_{\varepsilon}$.

According to this approach, the null hypothesis of perfect capital mobility can be tested in terms of the long-run derivative of $i$ with respect to a permanent change in $s$. If $\lim _{k \rightarrow \infty} \partial s_{t+k} / \partial \varepsilon_{t}^{S} \neq 0$, then $L R D_{i, s}=\lim _{k \rightarrow \infty} \frac{\partial i_{t+k} / \partial \varepsilon_{t}^{s}}{\partial s_{t+k} / \partial \varepsilon_{t}^{s}}$ and expresses the effect of an exogenous saving-to-output ratio disturbance on $i$, relative to that disturbance's effect on $s$. When $\lim _{k \rightarrow \infty} \partial s_{t+k} / \partial i_{t+k}=0$, there are no permanent changes in $S$ and the $L R D_{i, s}$ is undefined. In terms of this framework, perfect capital mobility requires that $L R D_{i, s}=0$. The above bivariate autoregressive system (1) and (2) can be inverted into

$$
\begin{aligned}
& \Delta^{\langle i\rangle} i_{t}=\theta_{i s}(L) \varepsilon_{t}^{S}+\theta_{i i}(L) \varepsilon_{t}^{i} \\
& \Delta^{\langle S\rangle} s_{t}=\theta_{s s}(L) \varepsilon_{t}^{s}+\theta_{s i}(L) \varepsilon_{t}^{i}
\end{aligned}
$$

Fisher and Seater (1993) show that the $L R D_{i, s}$ depends on $\langle s\rangle-\langle i\rangle$, as follows 


$$
L R D_{i, S}=\frac{\left.(1-L)^{\langle s\rangle-\langle i\rangle} \theta_{i S}(L)\right|_{L=1}}{\theta_{S S}(1)}
$$

Hence, meaningful perfect international capital mobility tests can be conducted if both $i_{t}$ and $s_{t}$ satisfy certain non-stationarity conditions. In particular, capital mobility tests require that both $i_{t}$ and $s_{t}$ are at least $I(1)$ (non-stationary in levels and stationary at first differences) and of the same order of integration. In fact, when $\langle s\rangle=\langle i\rangle=1$, the long-run derivative becomes

$$
L R D_{i, s}=\frac{\theta_{i s}(1)}{\theta_{S S}(1)}
$$

where $\theta_{i s}(1)=\sum_{j=1}^{\infty} \theta_{i s}^{j}$ and $\theta_{S S}(1)=\sum_{j=1}^{\infty} \theta_{s S}^{j}$. The coefficient $\frac{\theta_{i s}(1)}{\theta_{s S}(1)}$ is the long-run value of the impulse response of $i$ with respect to $S$, suggesting that the $L R D_{i, s}$ can be interpreted as the long-run elasticity of $i$ with respect to $s$. Under the assumption that $\operatorname{cov}\left(\varepsilon_{t}^{i}, \varepsilon_{t}^{S}\right)=0$ and that $s$ is exogenous in the long-run, the coefficient $\frac{\theta_{i s}(1)}{\theta_{s S}(1)}$ equals the zero-frequency regression coefficient of $\Delta^{\langle i\rangle} i_{t}$ on $\Delta^{\langle s\rangle} s_{t}$. (see note 11 on Fisher and Seater, 1993). This estimator is given by $\lim _{k \rightarrow \infty} b_{k}$, where $b_{k}$ is the coefficient of the regression

$$
\sum_{j=0}^{k} \Delta^{\langle i\rangle} i_{t-j}=a_{k}+b_{k}\left(\sum_{j=0}^{k} \Delta^{\langle s\rangle} s_{t-j}\right)+\varepsilon_{k t}
$$

In fact, when $\langle s\rangle=\langle i\rangle=1$, consistent estimates of $b_{k}$ can be derived by ordinary least squares regressions on

$$
i_{t}-i_{t-k}=a_{k}+b_{k}\left(s_{t}-s_{t-k}\right)+\varepsilon_{k t}, \quad k=1,2, \ldots, K
$$

The null hypothesis of low capital mobility is $b_{k}=1$. If the null is not rejected across a range of kforecast horizons, the data supports the F-H hypothesis of low capital mobility. The bulk of the related literature examines only the regression of $i$ on $s$, nonetheless, we also reverse the roles of $i$ and $s$ on equation (8).

\section{Data and empirical results}

\subsection{The data}

In order to test the effect of savings on investment and vice versa, we compile an annual dataset of gross savings and gross investment ratios to GDP for Austria, Belgium, Denmark, Finland, France, Germany, Greece, Ireland, Italy, Netherlands, Portugal, Spain, Sweden, U.K, U.S. and Japan. Our data span the period 1970-2016 and are from the database of the World Bank national accounts data ${ }^{3}$. The selection of these EU countries is based on the fact that they are the earliest countries entering the EU and later the EMU, and thus there exists a considerable time to observe possible economic convergence in their macroeconomic data. Data for the U.S. and Japan are collected for comparison reasons, given the broad literature on the F-H hypothesis for these two economies.

\footnotetext{
${ }^{3}$ Gross savings data can be accessed at https://data.worldbank.org/indicator/NY.GNS.ICTR.ZS and the gross investment (referred as gross capital formation) at https://data.worldbank.org/indicator/NE.GDI.TOTL.ZS.
} 
Table 1: Descriptive Statistics

\begin{tabular}{|c|c|c|c|c|c|c|c|c|c|c|}
\hline & \multicolumn{5}{|c|}{ Panel A: Investment ratio } & \multicolumn{5}{|c|}{ Panel B: Savings ratio } \\
\hline & Mean & $\begin{array}{l}\text { Stand } \\
\text { ard } \\
\text { Deviat } \\
\text { ion }\end{array}$ & $\begin{array}{l}\text { Skewn } \\
\text { ess }\end{array}$ & $\begin{array}{l}\text { Kurto } \\
\text { sis }\end{array}$ & $\begin{array}{c}\text { Jarque } \\
\text {-Bera } \\
\text { test } \\
(\mathrm{p}- \\
\text { value) }\end{array}$ & Mean & $\begin{array}{c}\text { Stand } \\
\text { ard } \\
\text { Devia } \\
\text { tion }\end{array}$ & $\begin{array}{l}\text { Skewn } \\
\text { ess }\end{array}$ & $\begin{array}{c}\text { Kurto } \\
\text { sis }\end{array}$ & $\begin{array}{c}\text { Jarque- } \\
\text { Bera test } \\
\text { (p-value) }\end{array}$ \\
\hline Austria & 26.04 & 2.66 & 1.03 & 3.21 & 0.02 & 26.48 & 2.17 & 0.74 & 3.85 & 0.06 \\
\hline Belgium & 23.52 & 2.72 & 0.50 & 2.96 & 0.37 & 25.12 & 2.86 & -0.21 & 3.18 & 0.82 \\
\hline Denmark & 21.69 & 2.65 & 0.48 & 2.54 & 0.33 & 24.82 & 2.74 & -0.60 & 2.49 & 0.19 \\
\hline Finland & 25.54 & 4.38 & 0.67 & 2.78 & 0.17 & 27.48 & 3.54 & -0.75 & 2.56 & 0.09 \\
\hline France & 23.11 & 2.36 & 0.72 & 3.02 & 0.13 & 22.98 & 2.37 & 1.11 & 3.40 & 0.01 \\
\hline Germany & 23.27 & 3.34 & 0.75 & 3.49 & 0.09 & 24.38 & 2.33 & 0.64 & 3.55 & 0.15 \\
\hline Greece & 26.39 & 8.18 & 0.08 & 3.30 & 0.90 & 18.76 & 7.70 & 0.72 & 2.88 & 0.13 \\
\hline Ireland & 23.23 & 4.58 & 0.19 & 2.24 & 0.49 & 28.44 & 10.86 & 0.46 & 2.32 & 0.28 \\
\hline Italy & 21.68 & 2.67 & 0.40 & 3.34 & 0.47 & 22.28 & 1.86 & -0.03 & 2.73 & 0.93 \\
\hline Luxemburg & 21.18 & 2.48 & 0.31 & 2.45 & 0.51 & 41.01 & 8.07 & -0.14 & 1.85 & 0.25 \\
\hline $\begin{array}{l}\text { Netherland } \\
\mathrm{s}\end{array}$ & 22.48 & 2.28 & 0.88 & 4.58 & 0.00 & 28.44 & 1.71 & -0.69 & 2.84 & 0.15 \\
\hline Portugal & 25.23 & 5.17 & -0.22 & 2.71 & 0.76 & 18.15 & 3.36 & 0.20 & 2.73 & 0.80 \\
\hline Spain & 24.78 & 3.46 & 0.27 & 2.09 & 0.34 & 23.17 & 1.96 & 0.23 & 2.25 & 0.47 \\
\hline Sweden & 24.63 & 3.44 & 0.71 & 2.67 & 0.13 & 28.19 & 2.39 & -0.17 & 2.76 & 0.84 \\
\hline UK & 20.17 & 3.45 & 0.48 & 2.07 & 0.17 & 19.15 & 4.06 & 0.05 & 1.66 & 0.17 \\
\hline US & 21.92 & 1.76 & -0.38 & 2.71 & 0.52 & 19.83 & 2.54 & -0.33 & 2.20 & 0.35 \\
\hline Japan & 29.51 & 5.12 & 0.27 & 2.31 & 0.47 & 30.51 & 5.42 & -0.07 & 2.33 & 0.64 \\
\hline $\begin{array}{l}\text { North } \\
\text { Eurozone }\end{array}$ & 23.55 & 3.10 & 0.63 & 3.09 & 0.22 & 28.04 & 4.24 & 0.14 & 2.94 & 0.23 \\
\hline $\begin{array}{l}\text { South } \\
\text { Eurozone }\end{array}$ & 24.52 & 4.87 & 0.13 & 2.86 & 0.62 & 20.59 & 3.72 & 0.28 & 2.65 & 0.58 \\
\hline North EU & 23.17 & 3.12 & 0.61 & 2.91 & 0.22 & 26.95 & 3.92 & 0.04 & 2.77 & 0.28 \\
\hline $\begin{array}{l}\text { Average } \\
\text { ratio for all } \\
\text { EU } \\
\text { countries of } \\
\text { the sample }\end{array}$ & & & 23.53 & & & & & 25.26 & & \\
\hline
\end{tabular}

In addition to the individual countries included in our sample, we also create 4 groups of countries. The first group labeled "north Eurozone" and includes Austria, Belgium, France, Germany, Ireland, Luxemburg and the Netherlands. The second group is labeled "south Eurozone" and includes the rest of the Eurozone countries: Greece, Italy, Portugal and Spain. This grouping is used in the effort to uncover possible differences in the investment and savings ratios because of the debt crises that hit the south Eurozone countries after 2010. Finally, we create the group "north EU" that augments the "north Eurozone" group with Denmark, Sweden and the U.K that did not adopt the euro. The south EU group is the same as the "south Eurozone" so we omit this group.

As we observe from Table 1, the mean investment ratio in the sample is $23.53 \%$ and the savings ratio is $25.26 \%$. Greece has an investment ratio of $26.39 \%$ that is the highest among the EU. This may be the result of the significant inflow of EU assets in the country and the rapid growth of the Greek GDP during the period 2006-2010. Nonetheless, Greece has the second lowest mean savings ratio at 
$18.76 \%$ passing only Portugal with $18.15 \%$ of its GDP. This reflects the big drop in private savings during the period 2014-2015 that lead to the imposition of capital controls on the Greek banking institutions on August 2015. The savings ratio for the north Eurozone is $28.04 \%$, which is $8 \%$ percent higher than the corresponding $20.59 \%$ savings ratio for the south Eurozone countries. The difference can be attributed to a large part to the small savings ratio in Greece and Portugal.

As stated in section 2, the long run derivative (LRD) can be defined only if both variables have certain non-stationarity properties. More specifically, both variables should be at least integrated of order one and of the same order of integration. In order to test for non-stationarity we apply the ADF (Dickey and Fuller, 1979), the Phillips and Perron (1998) and the KPSS (Kwiatkowski, Phillips, Schmidt, and Shin, 1992) tests. All tests include an intercept and a linear trend term. The lag order for the ADF test is determined according to the minimum SIC criterion (Schwarz, 1978). We use the Bartlett kernel for the PP and the KPSS test and determine the bandwidth of the kernel based on the Newey-West (1987) procedure. For the first two-unit root tests the null hypothesis is non-stationarity, while for the KPSS is stationarity. The results of the unit root tests are reported in Table 2. According to these, the investment and saving ratios are non-stationary in the levels and stationary in the first differences at $5 \%$ level of significance for all cases. Thus, the non-stationarity assumptions necessary to estimate the LRD are valid. 
Table 2: Unit root tests results

\begin{tabular}{|c|c|c|c|c|c|c|c|c|c|c|c|c|c|c|}
\hline & \multicolumn{7}{|c|}{ Panel A: Investment ratio as the dependent variable } & \multicolumn{7}{|c|}{ Panel B: Savings ratio as the dependent variable } \\
\hline & \multicolumn{3}{|c|}{ Levels } & \multicolumn{3}{|c|}{ First Differences } & \multirow[b]{2}{*}{$\begin{array}{l}\text { Decision } \\
\text { at the 5\% } \\
\text { level }\end{array}$} & \multicolumn{3}{|c|}{ Levels } & \multicolumn{3}{|c|}{ First Differences } & \multirow[b]{2}{*}{$\begin{array}{c}\text { Decision } \\
\text { at the 5\% } \\
\text { level }\end{array}$} \\
\hline & $\mathrm{ADF}$ & $\mathrm{PP}$ & KPSS & $\mathrm{ADF}$ & $\mathrm{PP}$ & KPSS & & $\mathrm{ADF}$ & $\mathrm{PP}$ & KPSS & $\mathrm{ADF}$ & PP & KPSS & \\
\hline Austria & -2.60 & -2.60 & 0.16 & $-6.55 * * *$ & $-6.55 * * *$ & 0.20 & $\mathrm{I}(1)$ & -2.17 & -2.19 & $0.63^{* *}$ & $-6.47 * * *$ & $-7.93 * * *$ & 0.11 & $\mathrm{I}(1)$ \\
\hline Belgium & -2.24 & -2.49 & 0.12 & $-6.06 * * *$ & $-6.05 * * *$ & 0.27 & $\mathrm{I}(1)$ & $-2.70^{*}$ & $-2.70^{*}$ & 0.30 & $-7.05^{* * *}$ & $-7.05 * * *$ & 0.21 & $\mathrm{I}(1)$ \\
\hline Denmark & -1.26 & -1.46 & $0.54^{* *}$ & $-5.27 * * *$ & $-5.15 * * *$ & 0.09 & $\mathrm{I}(1)$ & $-2.83^{*}$ & $-2.74^{*}$ & 0.34 & $-6.18 * * *$ & $-6.15^{* * *}$ & 0.09 & $\mathrm{I}(1)$ \\
\hline Finland & -1.76 & -1.38 & 0.35 & $-5.83 * * *$ & $-5.77 * * *$ & 0.11 & $\mathrm{I}(1)$ & -2.57 & -1.80 & $0.70 * *$ & $-5.51 * * *$ & $-6.82 * * *$ & 0.22 & $\mathrm{I}(1)$ \\
\hline France & -2.42 & -2.33 & $0.56^{* *}$ & $-5.29 * * *$ & $-5.21 * * *$ & 0.18 & $\mathrm{I}(1)$ & -2.48 & -2.44 & $0.47^{* *}$ & $-7.24 * * *$ & $-7.27 * * *$ & 0.20 & $\mathrm{I}(1)$ \\
\hline Germany & $-2.93 *$ & $-2.95^{*}$ & 0.18 & $-5.42 * * *$ & $-5.73 * * *$ & $0.42 *$ & $\mathrm{I}(1)$ & $-2.69 *$ & $-2.69 *$ & $0.82 * * *$ & $-5.75 * * *$ & $-5.51 * * *$ & 0.15 & $\mathrm{I}(1)$ \\
\hline Greece & -1.18 & -1.03 & $0.81^{* * *}$ & $-7.83^{* * *}$ & $-8.15 * * *$ & 0.06 & $\mathrm{I}(1)$ & -0.85 & -0.59 & $0.77^{* * *}$ & $-7.70 * * *$ & $-7.98 * * *$ & 0.09 & $\mathrm{I}(1)$ \\
\hline Ireland & 0.50 & 0.50 & $0.85^{* * *}$ & $-5.77 * * *$ & $-5.77 * * *$ & 0.18 & $\mathrm{I}(1)$ & $-2.66^{*}$ & -1.94 & 0.11 & $-4.73 * * *$ & $-4.73 * * *$ & 0.14 & $\mathrm{I}(1)$ \\
\hline Italy & -1.55 & -2.03 & $0.75^{* * *}$ & $-6.91 * * *$ & $-7.24 * * *$ & 0.17 & $\mathrm{I}(1)$ & -2.05 & -1.77 & $0.73^{* *}$ & $-8.94 * * *$ & $-10.40 * * *$ & $0.41^{*}$ & $\mathrm{I}(1)$ \\
\hline Luxemburg & -0.81 & -0.78 & $0.70^{* * *}$ & $-7.52 * * *$ & $-7.74 * * *$ & 0.27 & $\mathrm{I}(1)$ & $-2.83^{*}$ & $-2.73 *$ & $0.39 *$ & $-8.93 * * *$ & $-8.98 * * *$ & 0.11 & $\mathrm{I}(1)$ \\
\hline Netherlands & -1.70 & -1.70 & 0.34 & $-5.82 * * *$ & $-5.77 * * *$ & 0.16 & $\mathrm{I}(1)$ & $-3.46 * *$ & $-3.40^{* *}$ & $0.61 * *$ & $-5.58 * * *$ & $-5.56 * * *$ & 0.19 & $\mathrm{I}(1)$ \\
\hline Portugal & $-3.65 * *$ & $-2.61 *$ & $0.68 * *$ & $-5.13 * * *$ & $-7.89 * * *$ & $0.45^{*}$ & $\mathrm{I}(1)$ & -2.13 & -1.32 & $0.61^{* *}$ & $-4.90 * * *$ & $-6.13 * * *$ & 0.24 & $\mathrm{I}(1)$ \\
\hline Spain & $-3.01 * *$ & -2.19 & 0.14 & $-3.77 * * *$ & $-4.52 * * *$ & 0.19 & $\mathrm{I}(1)$ & -2.51 & -1.96 & 0.11 & $-4.05 * * *$ & $-4.14 * * *$ & 0.07 & $\mathrm{I}(1)$ \\
\hline Sweden & $-3.50 * *$ & $-2.88^{*}$ & 0.12 & $-5.81 * * *$ & $-5.41 * * *$ & 0.26 & $\mathrm{I}(1)$ & $-2.90^{*}$ & $-2.88^{*}$ & $0.57^{* *}$ & $-5.92 * * *$ & $-6.88 * * *$ & $0.38^{*}$ & $\mathrm{I}(1)$ \\
\hline UK & -1.16 & -1.04 & $0.84^{* * *}$ & $-6.39 * * *$ & $-7.14 * * *$ & 0.17 & $\mathrm{I}(1)$ & -1.61 & -1.39 & $0.78 * * *$ & $-5.81 * * *$ & $-6.69 * * *$ & 0.10 & $\mathrm{I}(1)$ \\
\hline US & -0.96 & -0.96 & $0.77^{* * *}$ & $-6.06 * * *$ & $-6.06 * * *$ & 0.07 & $\mathrm{I}(1)$ & -2.09 & -2.26 & $0.48^{* *}$ & $-6.03 * * *$ & $-6.23 * * *$ & 0.14 & $\mathrm{I}(1)$ \\
\hline Japan & -1.96 & -1.91 & $0.80 * * *$ & $-5.28 * * *$ & $-5.30 * * *$ & 0.17 & $\mathrm{I}(1)$ & -1.33 & -2.04 & $0.81 * * *$ & $-5.45 * * *$ & $-5.59 * * *$ & 0.18 & $\mathrm{I}(1)$ \\
\hline
\end{tabular}

Note: All tests include an intercept and a linear trend. *,** and *** denote rejection of the null hypothesis at $10 \%, 5 \%$ and $1 \%$ level of significance. Cases where we get inconclusive results between the tests are considered as I(1). All models include an intercept. 


\subsection{Long Run Derivative estimation}

We estimate equation (8) and get the values of $b_{k}$ for $k=1,2, \ldots ., 30$, based on Newey-West (1987) robust standard errors, for the entire 1960-2015 sample. The lag length is calculated according to Andrews and Monohan (1992) and in our case we fix it at 4 and the Bartlett kernel is used in these calculations. We also apply the small sample correction proposed by Andrews (1991) to the estimated covariance matrix $T / d$, where $T$ is the sample length and $d$ represents the corresponding degrees of freedom.

A potential issue in this analysis is the relatively small number of observations (56) that could lead to a few degrees of freedom and thus a low power of the test to reject a false null hypothesis, leading to Type II error. In order to examine the robustness of our results, in the cases that we cannot reject the null hypothesis of no capital mobility $H_{0}: b_{k}=1$, we employ the Inverse Power Function (IPF) of Andrews (1991) and we examine IPFs for both high and low probability of Type II error. According to Andrews (1991), $\Omega=\left(-\infty, 1-b_{k, 0.05}\right] \cup\left[1+b_{k, 0.05},+\infty\right)$ defines the region where the probability of Type II error is small (5\% or less), with $b_{q, a}=\lambda_{q, a}(1-\gamma) \hat{\sigma}_{b_{k}}$, where $\gamma$ is the probability of Type II error, $\hat{\sigma}_{b_{k}}$ is the robust standard error of $\hat{b}_{k}, q$ is the number of restrictions and $a$ the significance level of the test. When we fail to reject the null, we can say with $95 \%$ probability that the true value of the coefficient $b_{k}$ lies at $1-b_{k, 0.05}<b_{k}<1+b_{k, 0.05}$. Similarly, we define the region with high probability of Type II error $\Psi=\left[1-b_{k, 0.50}, 1+b_{k, 0.50}\right]$ where there is $50 \%$ or higher chance of not rejecting a false null. If $\hat{b}_{k} \in \Psi$ then the test would have rejected a false null with a probability of $50 \%$ or less. In this case we have a greater chance of rejecting a false null by tossing a coin than using the test. Thus, when we cannot reject the null:

a) If the estimate lies in the $\Omega$ region, we are sure that the non-rejection is not due to the small sample and the corresponding low power of the test. The test has enough power (probability of Type II error $5 \%$ or less) to reject a false null.

b) If the estimate lies in the $\Psi$ area, the test has low power and the non-rejection may be the result of the small sample size and thus the probability of Type II error is high (50\% or more). In other words the resuls is ambiguous; we cannot accept or reject the null hypothesis.

c) Finally, in the area between the boundaries of the $\Psi$ and $\Omega$ regions the probability of a Type II error is less than $50 \%$ and more than $5 \%$.

From Andrews (1991, Table 1) we get that $\lambda_{1,0.05}(0.95)=3.605$ and $\lambda_{1,0.05}(0.50)=1.96$. In Figures 1-16 we depict the values of the coefficient $\hat{b}_{k}$ along with the corresponding IPF bounds. The left panel assumes investment as the dependent variable, while in the right savings is the dependent variable. The continuous (blue) line depicts the estimated coefficient value $\hat{b}_{k}$, the dashed (red) lines defines the boundaries of the $\psi$ region and the continuous (green) lines with the $\mathrm{x}$ markers define the boundaries of the $\Omega$ region. The $95 \%$ confidence intervals are depicted as a shaded area. 


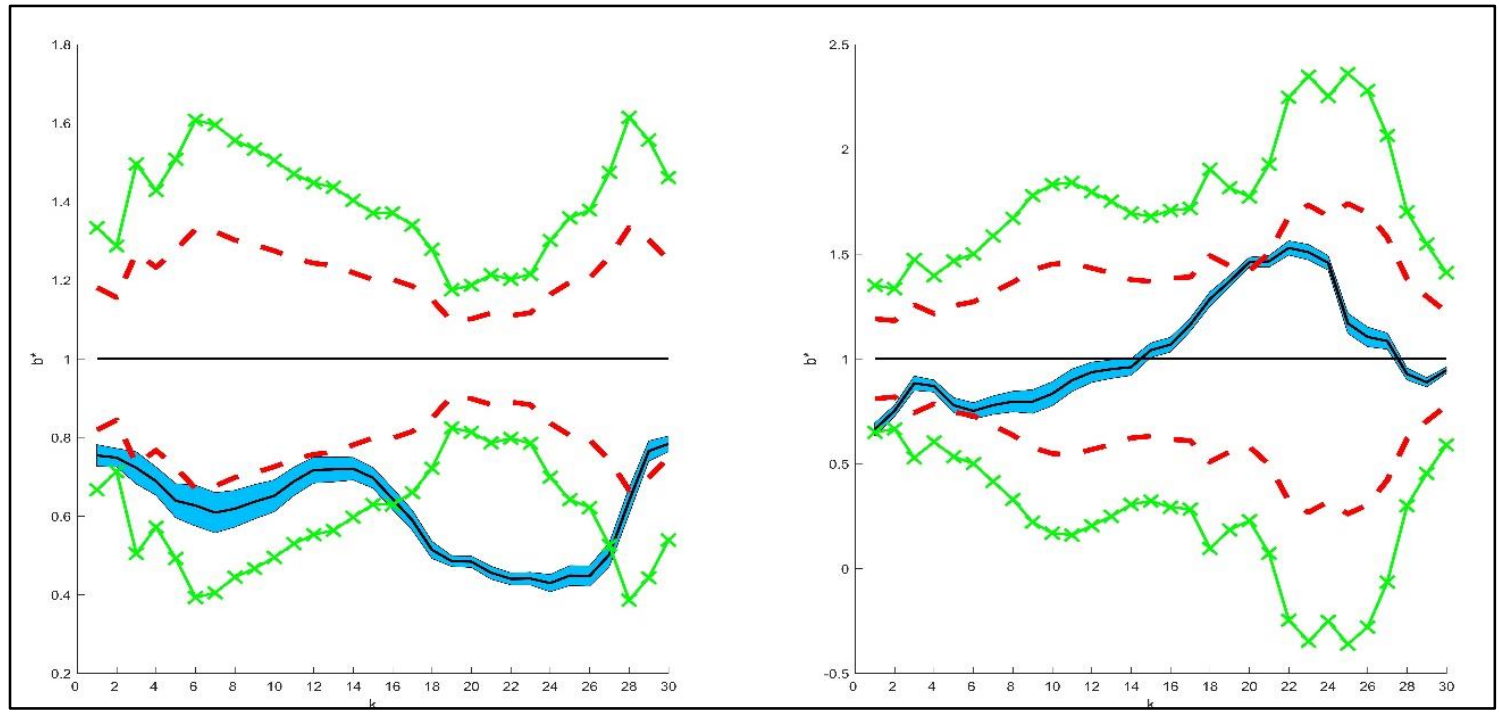

Figure 1: LRD and IPF values for Austria.

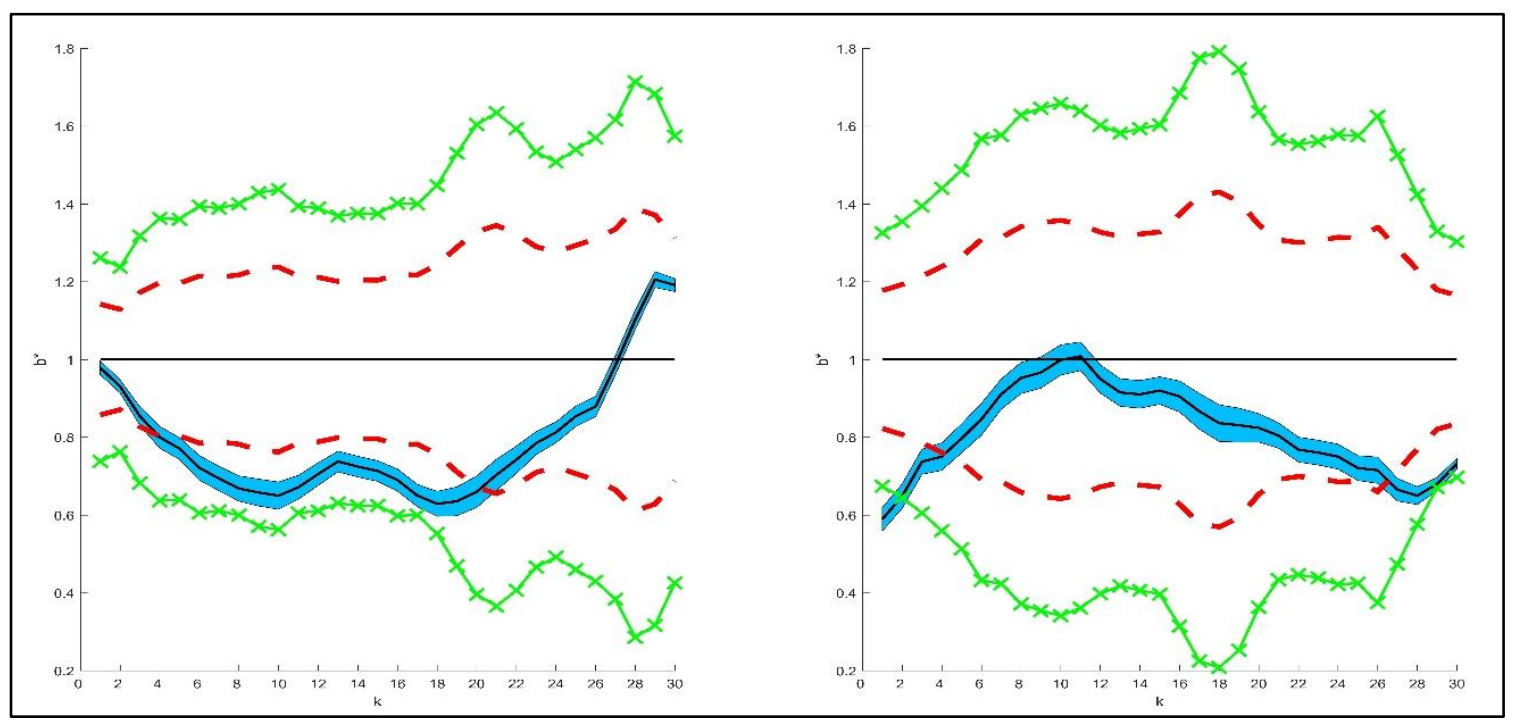

Figure 2: LRD and IPF values for Belgium.

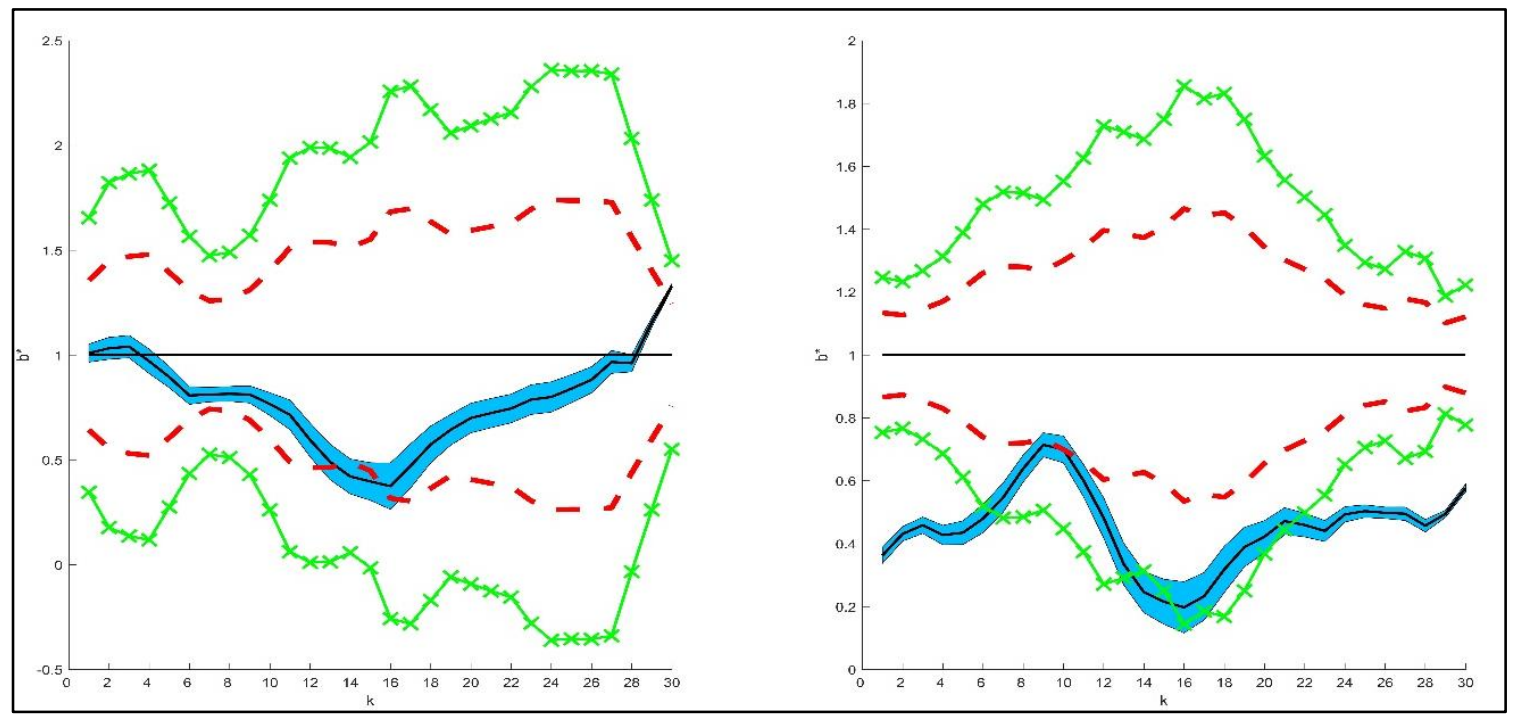

Figure 3: LRD and IPF values for Denmark. 


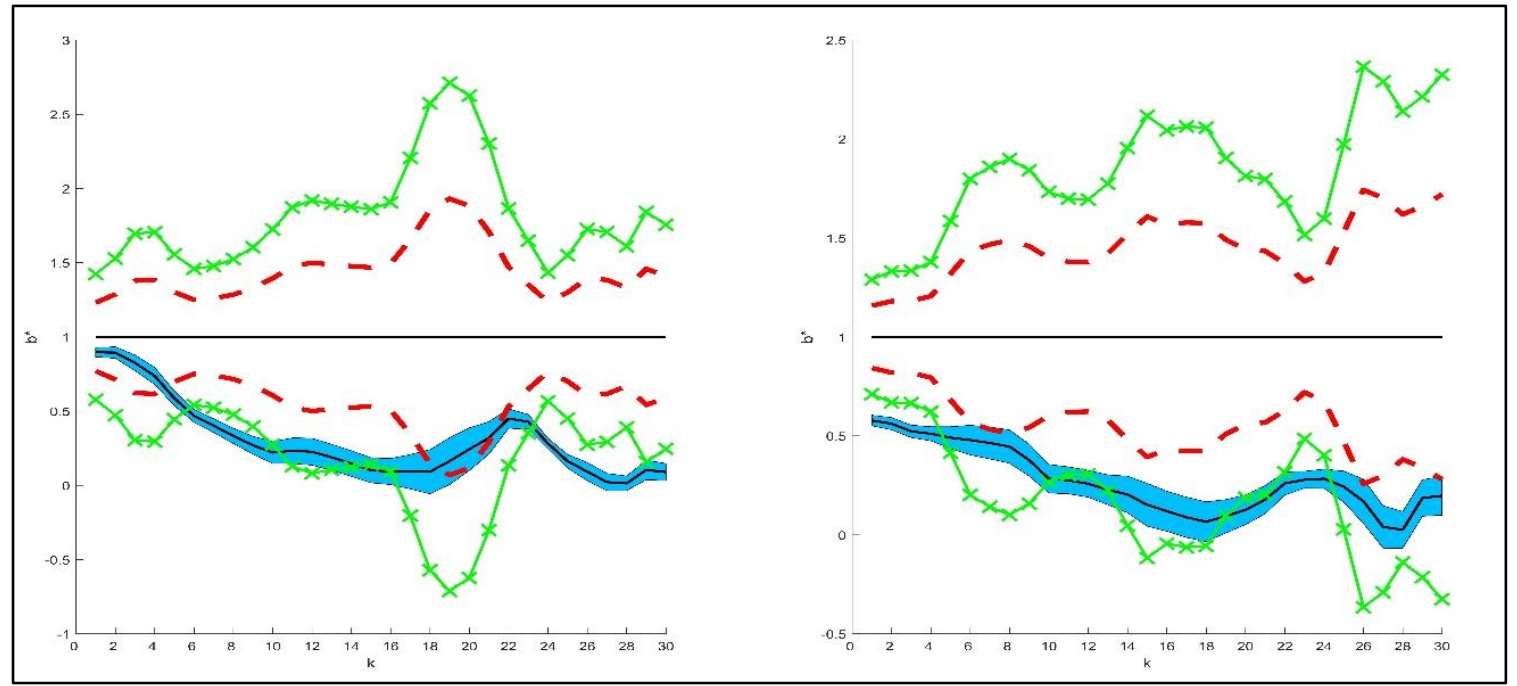

Figure 4: LRD and IPF values for Finland.

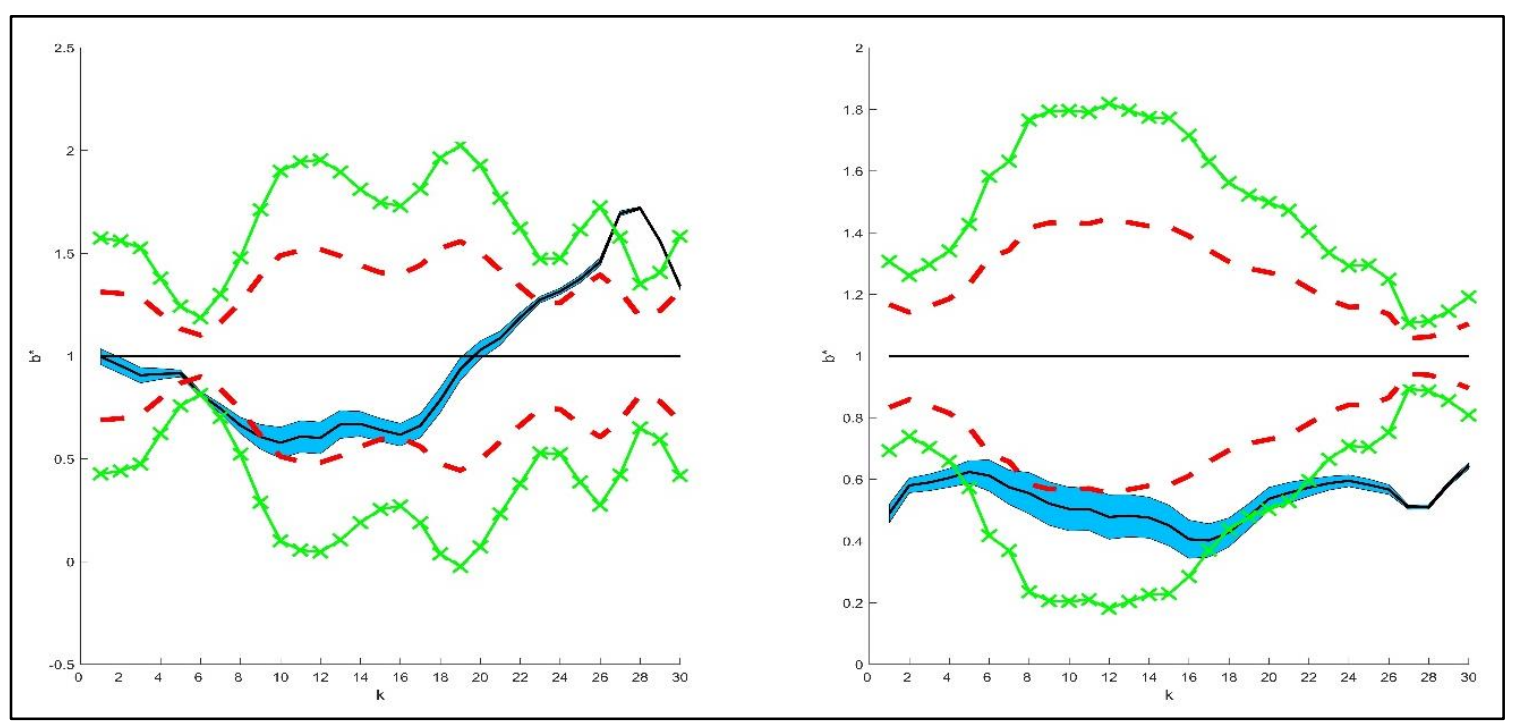

Figure 5: LRD and IPF values for France.

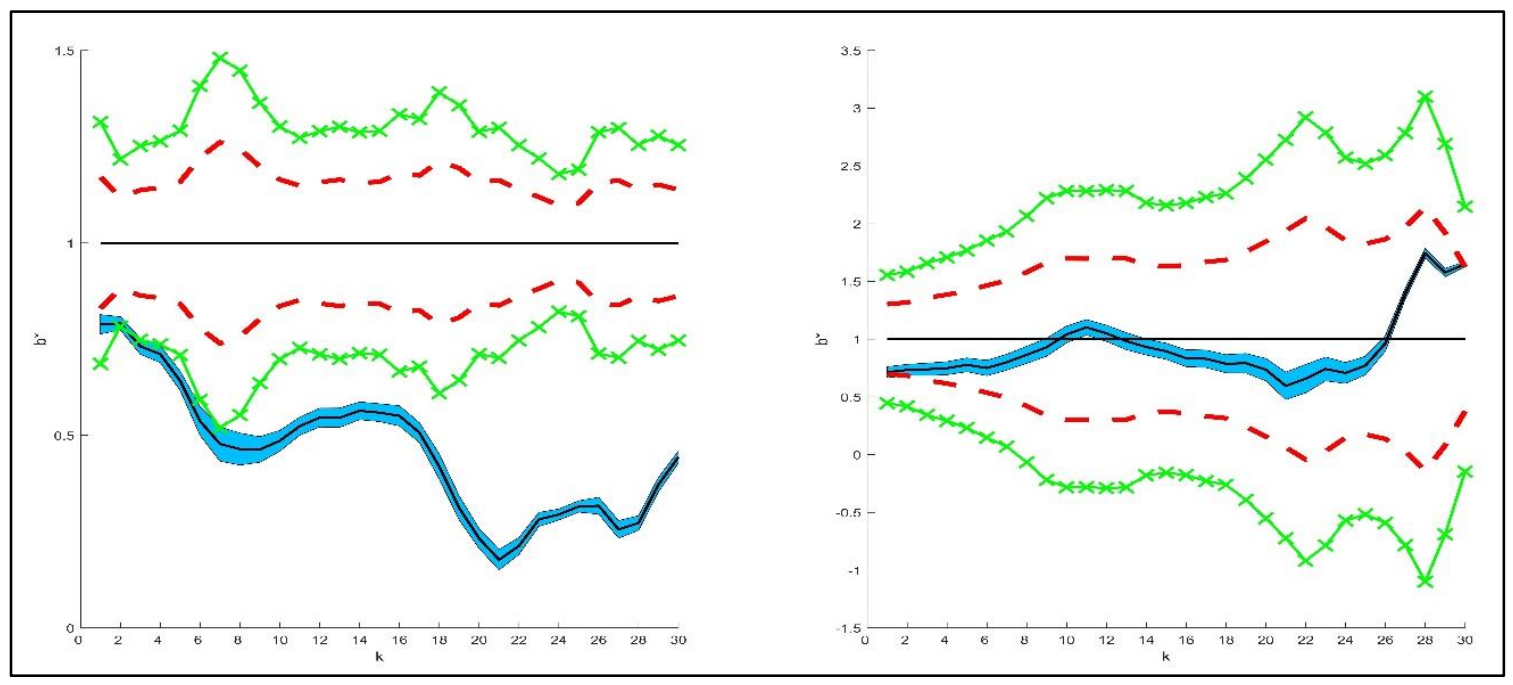

Figure 6: LRD and IPF values for Germany. 


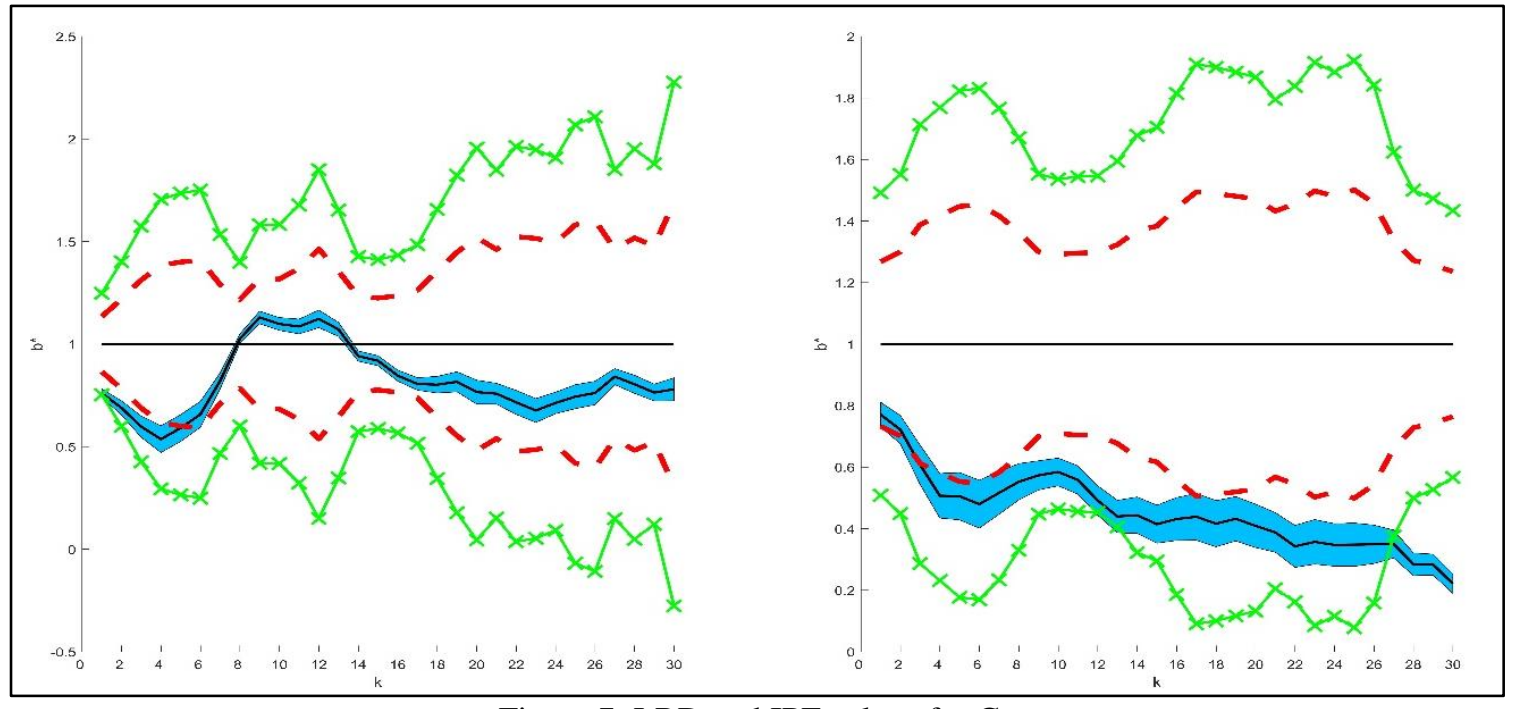

Figure 7: LRD and IPF values for Greece.

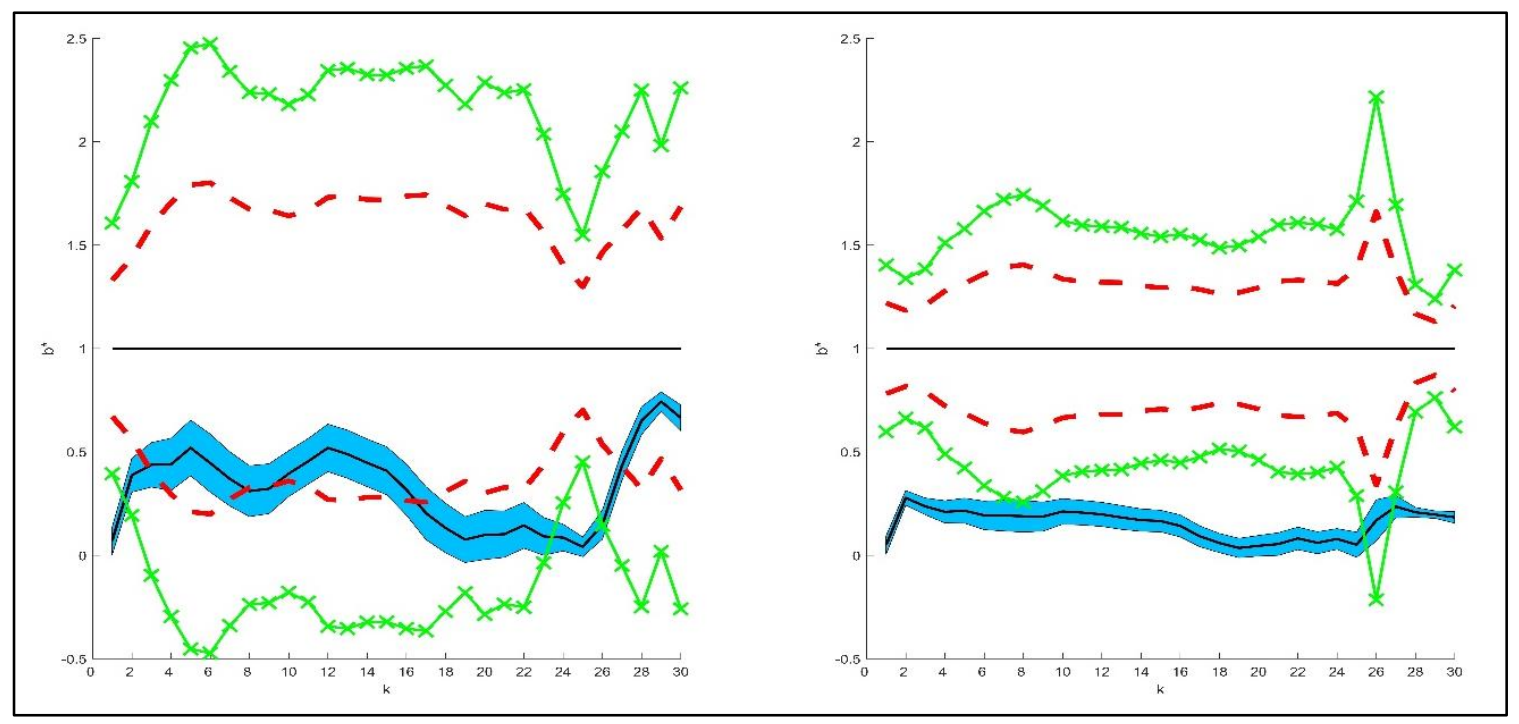

Figure 8: LRD and IPF values for Ireland.

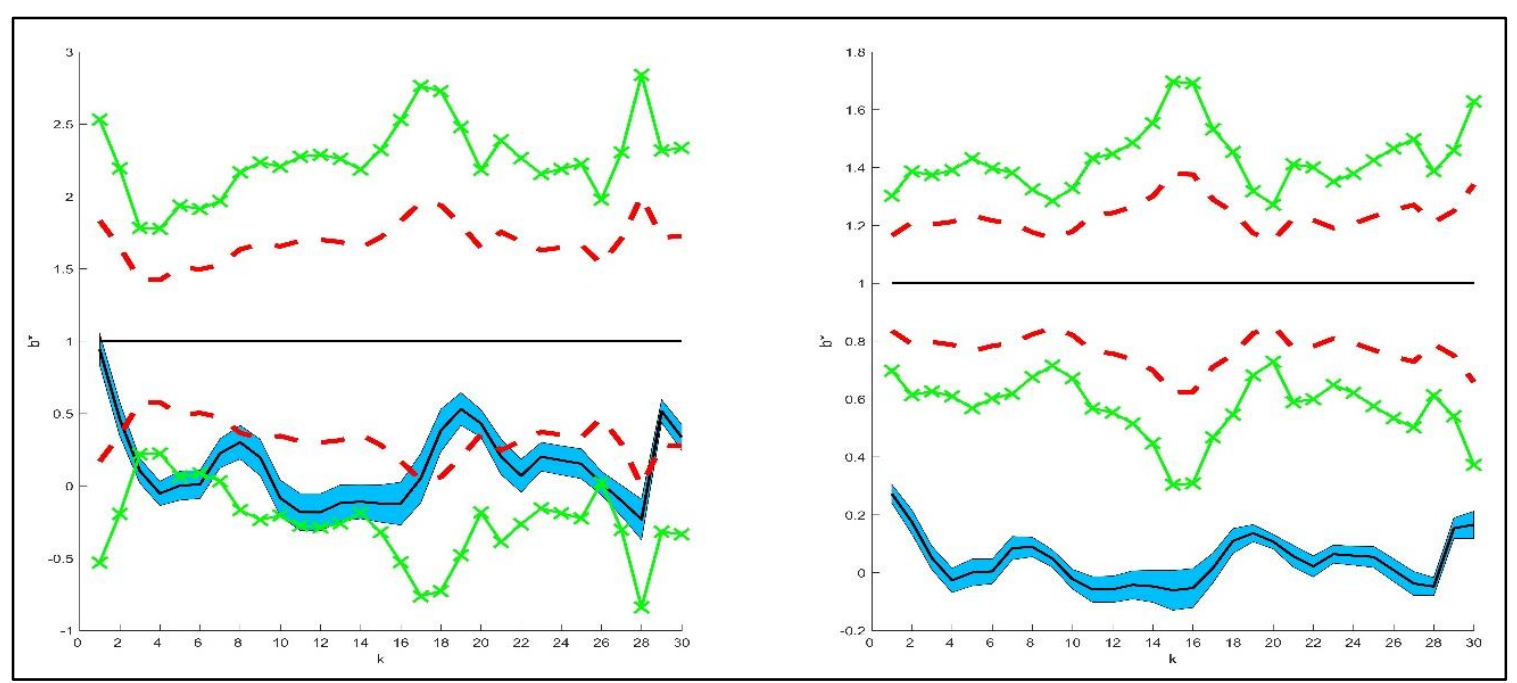

Figure 9: LRD and IPF values for Italy. 


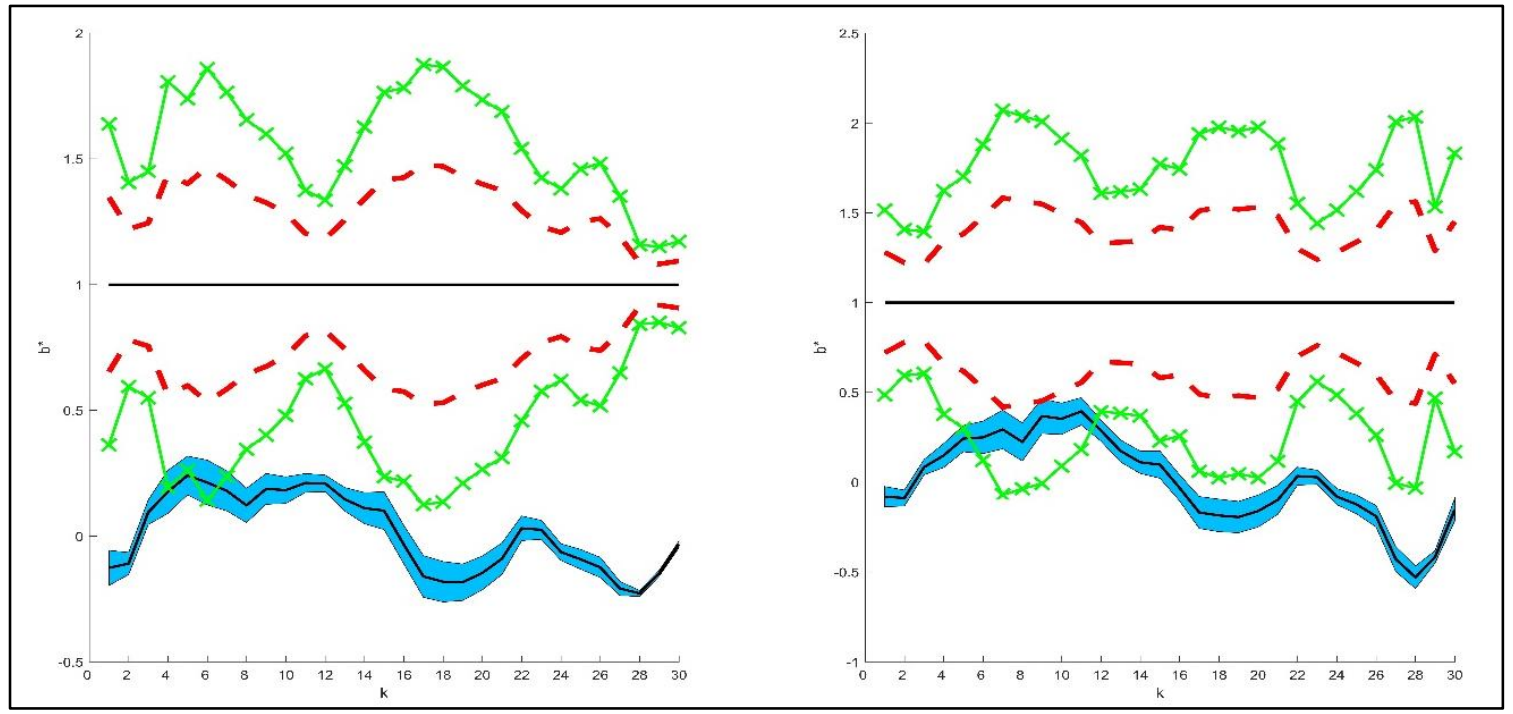

Figure 10: LRD and IPF values for Luxemburg.

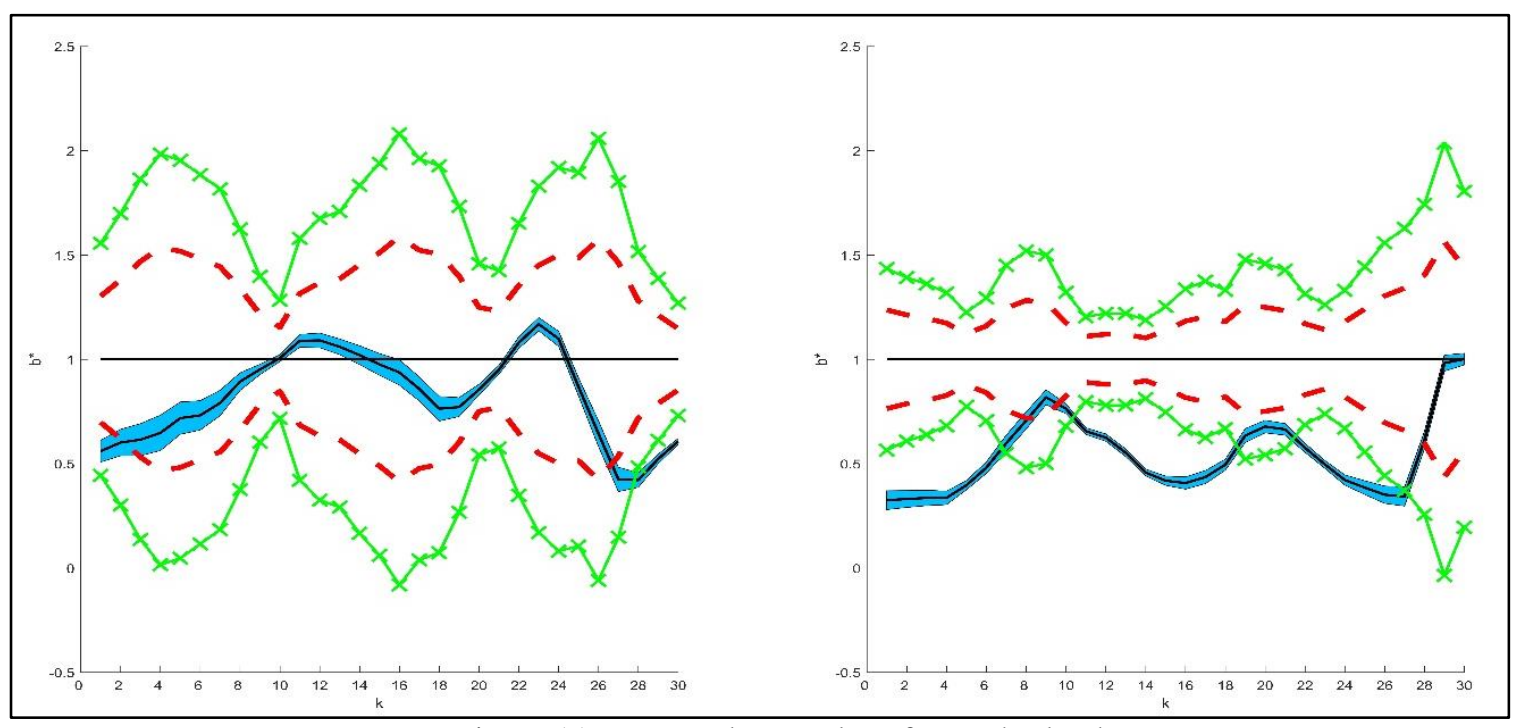

Figure 11: LRD and IPF values for Netherlands.

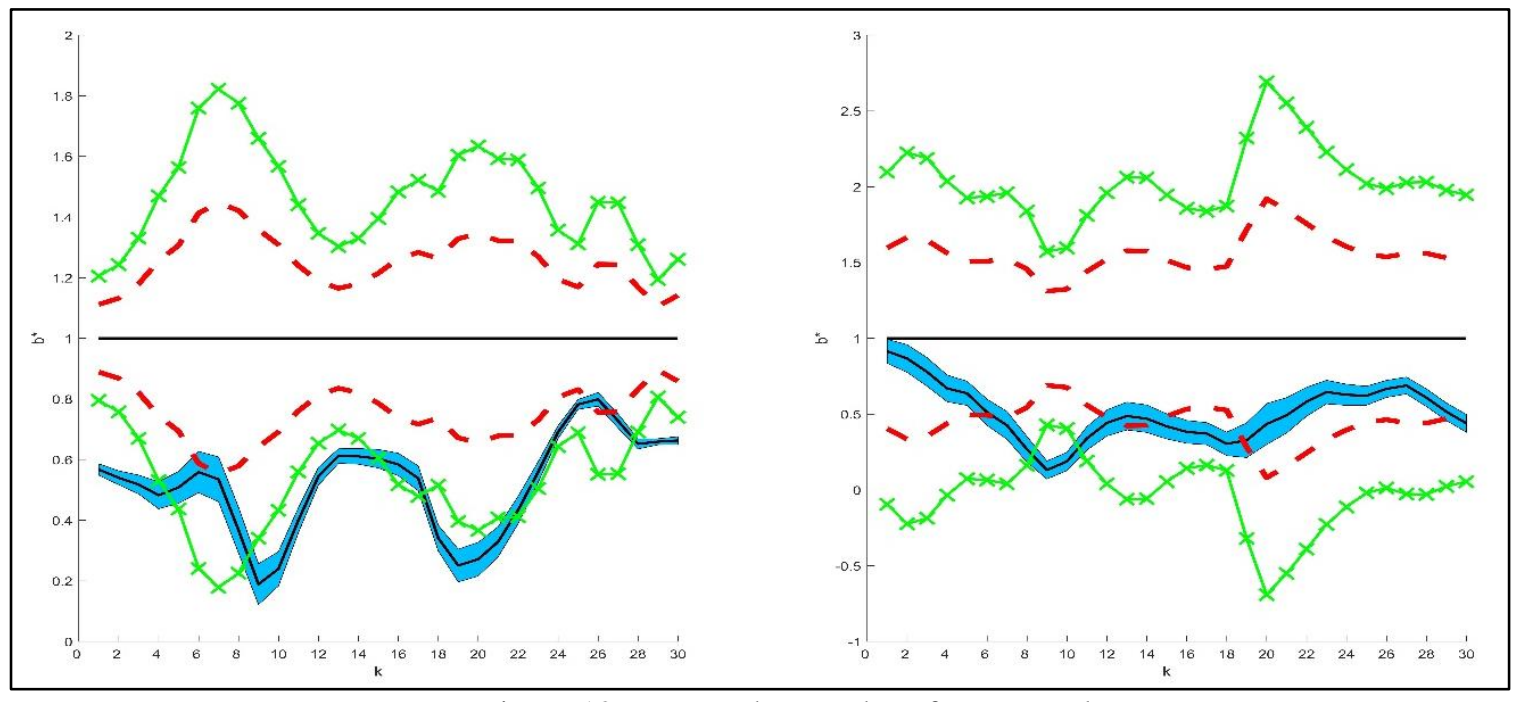

Figure 12: LRD and IPF values for Portugal. 


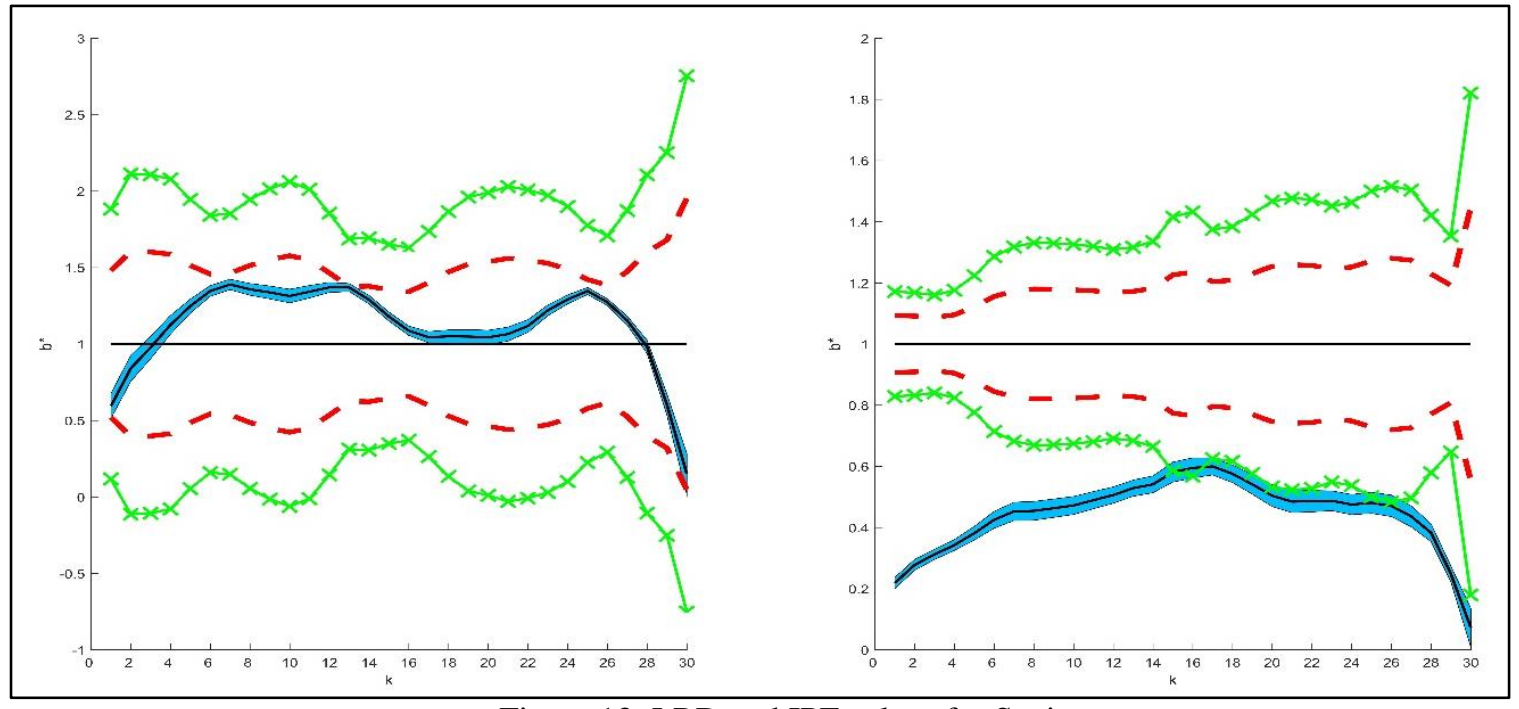

Figure 13: LRD and IPF values for Spain.

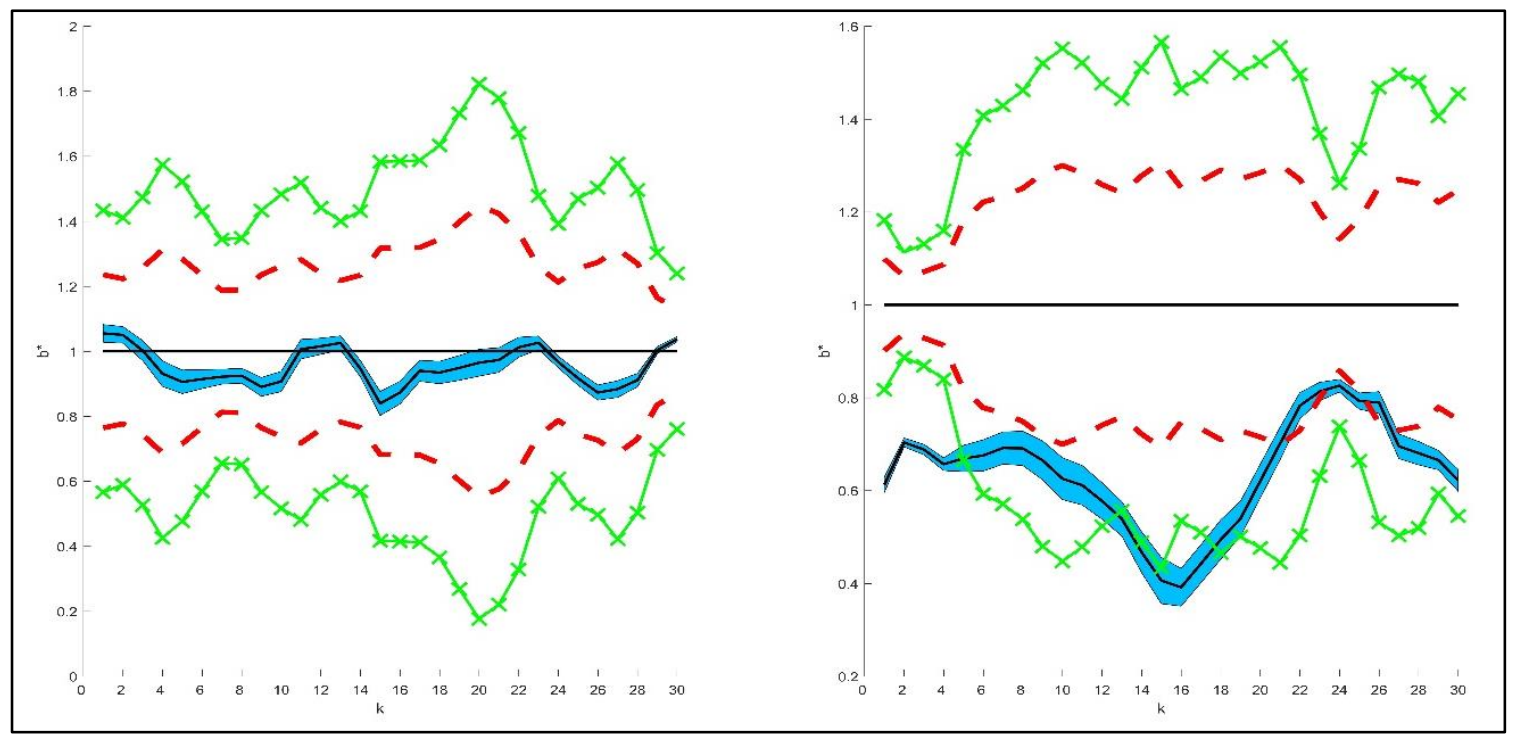

Figure 14: LRD and IPF values for Sweden.

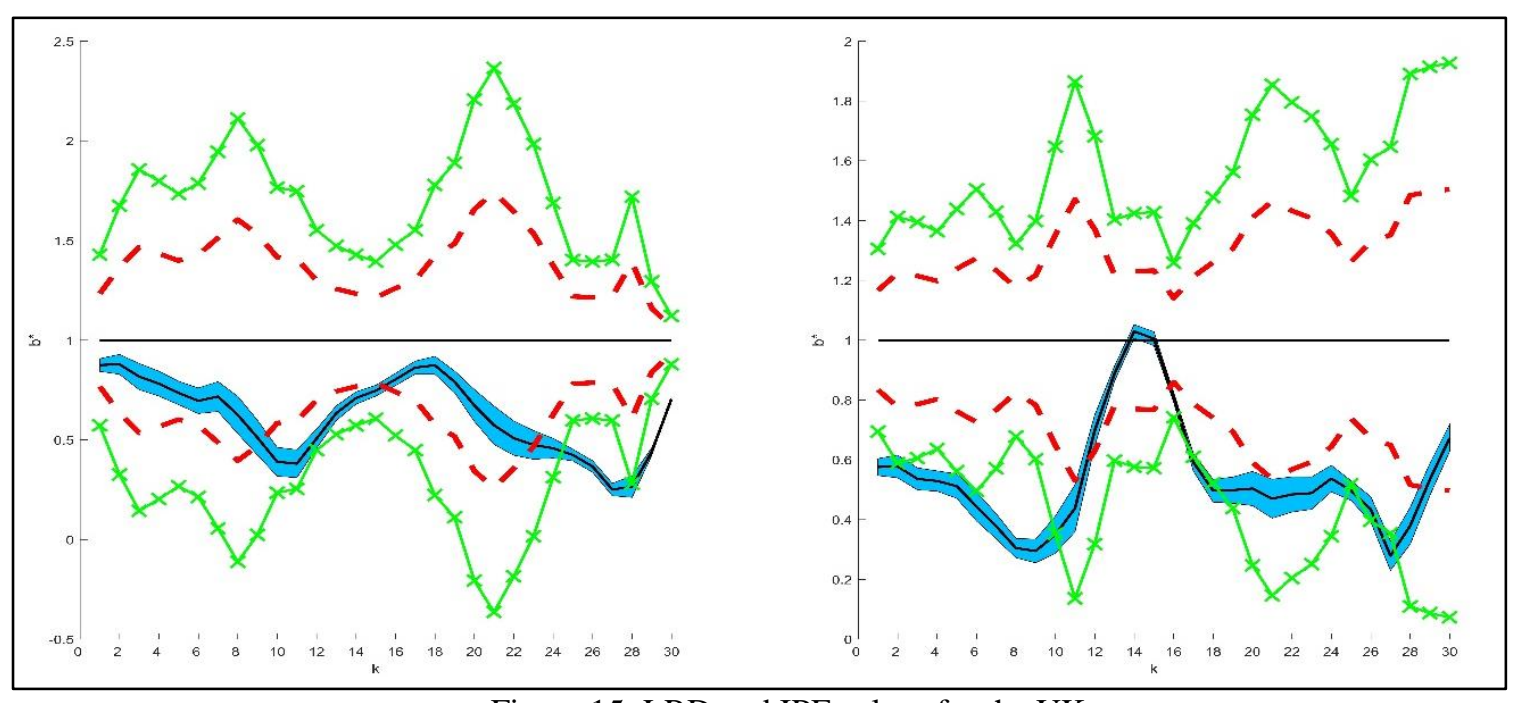

Figure 15: LRD and IPF values for the UK. 


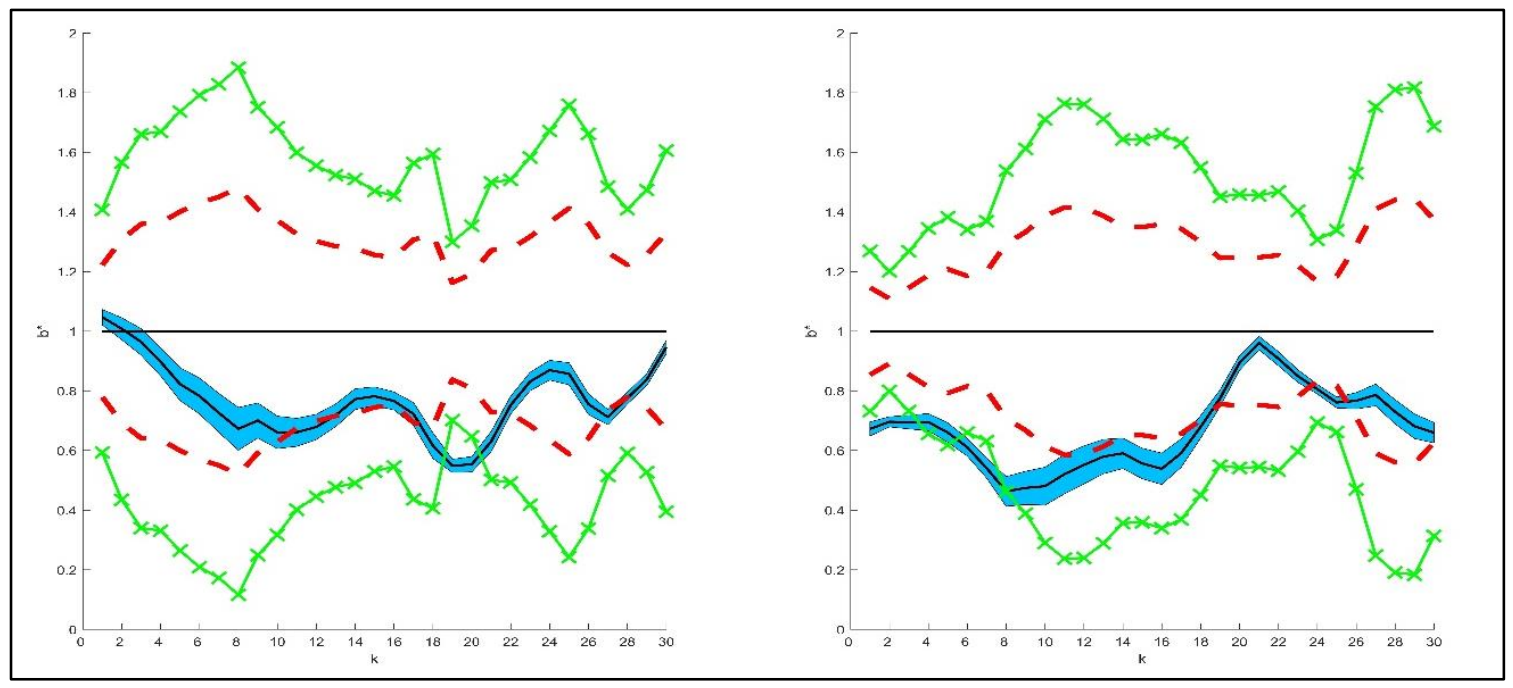

Figure 16: LRD and IPF values for the US.

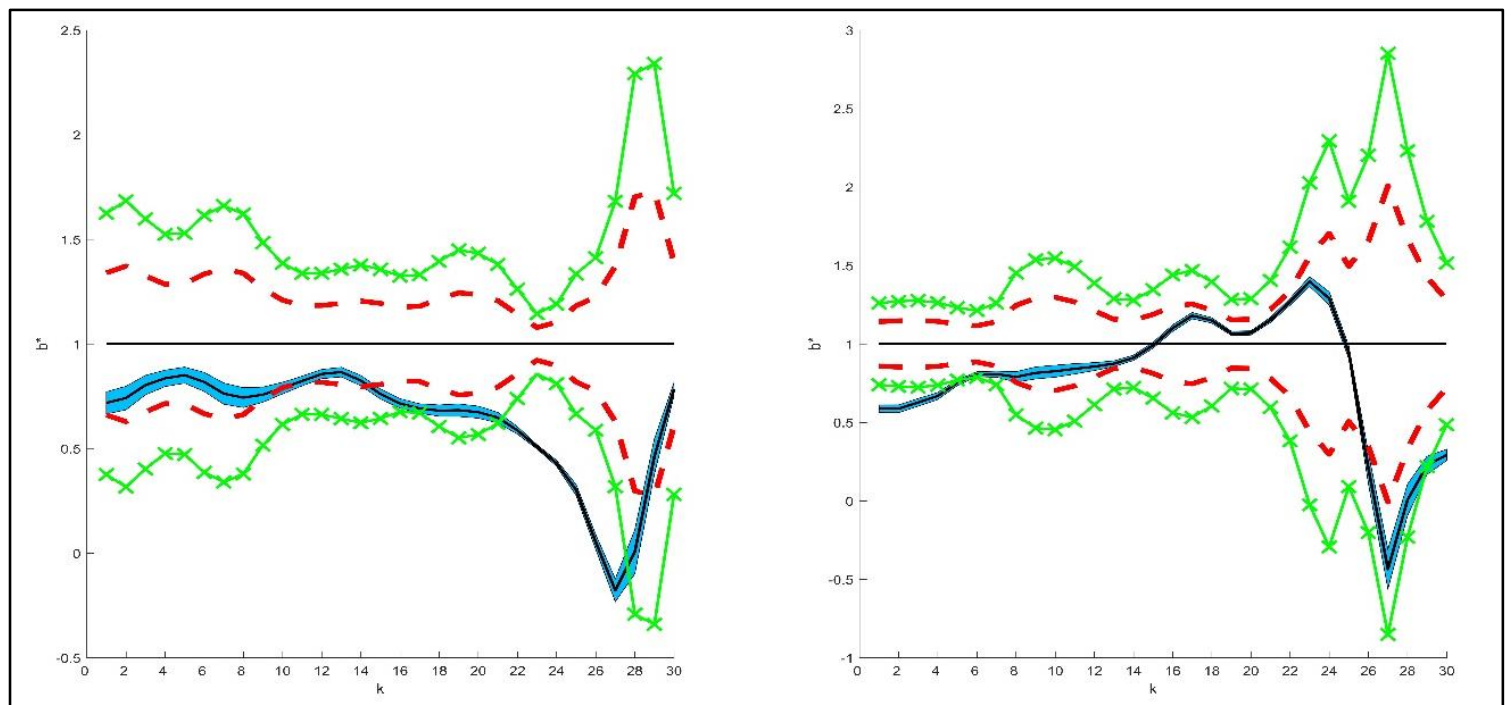

Figure 17: LRD and IPF values for Japan.

As we observe, we reject the null hypothesis that $b_{k}=1$ for all countries when the investment ratio is the dependent variable (left-hand side plots) for almost all lags. Some notable exceptions are 14-16 lags for the Netherlands and the periods 10-14 lags and 22-26 lags for Sweden while we observe several crossings from the $b_{k}=1$ line that is only episodical evidence. Nevertheless, in all cases where the value of the confidence bands of the estimated coefficient include 1 , that value lies outside the $\Omega$ region, indicating high probability of a type II error. Our empirical findings indicate similar results for all cases where the savings ratio is the dependent variable (right-hand side plots). From the examination of figures 16 and 17 we can also reject the null of no capital mobility for the US and Japan.

\subsection{Robustness check with panel estimation}

The fact that we have only 47 observations for the LRD estimation could be a point of criticism to our results. In order to enhance the robustness of our findings we perform causality test based on panel regressions between investment and savings. In doing so, we evaluate the typical Granger causality test and the approach of Dumitrescu and Hurlin (2012). The existence of a causal relationship between investment and savings excludes capital immobility, corroborating to the rejection of $b_{k}=1$. The typical Granger Causality test on stacked data in panel estimation assumes that all coefficients are the same across all cross-sections (data from one cross-section do not enter the lagged values of data 
from the next cross-section). Dumitrescu and Hurlin (2012) consider this assumption restrictive and argue that all coefficients are different across cross-sections. In other words they test whether causality is present for some proportion of the cross-sectional structure and to all cross-sections simultaneously. So, they perform standard Granger Causality regressions for each cross-section individually testing the null hypothesis of homogeneous causation between variables. Then, they average test statistics, which are termed the $W_{b a r}$ statistic for the entire panel. Based on the assumption that the standardized version of this statistic (appropriately weighted in unbalanced panels) follows the standard normal distribution. This is termed the $\bar{Z}_{\text {bar }}$ statistic. In Table 3, we report the panel causality tests results. Both tests examine the null hypothesis of no causal relationship between savings and investment.

Table 3: Panel Causality Tests

\begin{tabular}{|c|c|c|c|c|c|c|c|c|c|}
\hline & \multicolumn{3}{|c|}{ All countries } & \multicolumn{3}{|c|}{ European Union countries } & \multicolumn{3}{|c|}{ Eurozone countries } \\
\hline & \multirow{2}{*}{$\begin{array}{c}\text { Granger } \\
\text { Fstat }\end{array}$} & \multicolumn{2}{|c|}{$\begin{array}{c}\text { Dumitrescu and } \\
\text { Hurlin }\end{array}$} & \multirow{2}{*}{$\begin{array}{c}\text { Granger } \\
\text { Fstat } \\
\end{array}$} & \multicolumn{2}{|c|}{$\begin{array}{c}\text { Dumitrescu and } \\
\text { Hurlin }\end{array}$} & \multirow{2}{*}{$\begin{array}{c}\text { Granger } \\
\text { Fstat } \\
\end{array}$} & \multicolumn{2}{|c|}{$\begin{array}{c}\text { Dumitrescu and } \\
\text { Hurlin }\end{array}$} \\
\hline Lags & & $W_{\text {bar }}$ & $\bar{Z}_{\text {bar }}$ & & $W_{b a r}$ & $\bar{Z}_{\text {bar }}$ & & $W_{\text {bar }}$ & $\bar{Z}_{\text {bar }}$ \\
\hline \multicolumn{10}{|c|}{ Panel A: Null Hypothesis: Savings does not granger cause Investment } \\
\hline 1 & $4.18^{*}$ & $0.23 *$ & $-2.19 *$ & $3.69 *$ & $0.23 *$ & $-2.06^{*}$ & $4.18^{*}$ & 0.86 & -0.43 \\
\hline 2 & & & 1.30 & $23.47 *$ & & 1.21 & $26.63^{*}$ & 0.93 & -1.83 \\
\hline 3 & & & -0.84 & 15.3 & 2.6 & -0.79 & $17.38^{*}$ & $0.74 *$ & $-3.03 *$ \\
\hline 4 & & 5.9 & $2.08 *$ & 27.6 & 5.9 & 1.96 & $31.37 *$ & 2.46 & -1.87 \\
\hline 5 & $33.60 *$ & & $2.24 *$ & 29.5 & 7.4 & $2.11^{*}$ & $33.60^{*}$ & 5.63 & 0.26 \\
\hline 10 & $50.54 *$ & 13.30 & 1.07 & $44.39 *$ & 13.30 & 1.00 & $50.54 *$ & $5.13^{*}$ & $-3.02 *$ \\
\hline \multicolumn{10}{|c|}{ Panel B: Null Hypothesis: Investment does not granger cause Savings } \\
\hline 1 & $121.58^{*}$ & & $15.17^{*}$ & $107.22 *$ & $6.71 *$ & $14.25 *$ & $121.58^{*}$ & $2.96^{*}$ & $4.29 *$ \\
\hline 2 & & & & & & $8.08 *$ & $63.97 *$ & 3.4 & $2.03 *$ \\
\hline 3 & $103.54 *$ & 15.5 & $18.31 *$ & & & $17.20 *$ & $103.54 *$ & 3.8 & 0.90 \\
\hline 4 & & & $12.41 *$ & & & $11.65^{*}$ & $75.14 *$ & 5.11 & 0.91 \\
\hline 5 & & 11.14 & $6.30 *$ & $44.49 *$ & $11.14^{*}$ & $5.92 *$ & $50.52 *$ & $7.58^{*}$ & $2.04 *$ \\
\hline 10 & $51.05^{*}$ & 13.43 & 1.14 & $44.84 *$ & 13.13 & 1.08 & $51.05^{*}$ & 15.21 & 1.81 \\
\hline
\end{tabular}

Note: $*$ denotes rejection of the null hypothesis of no causal relationship at the $5 \%$ level of significance.

As we observe from Panel A of Table 3, savings granger cause investment for all countries of our sample up to 10 lags (years) based on the Granger test and for lags 1, 4 and 5 for the Dumitrescu and Hurlin test. When we focus only on European Union members, the typical Granger test rejects the null on all lags, but the Dimitrescu and Hurlin test does so only for lags 1 and 5. The picture is similar for Eurozone countries for lags 3 and 10. So, while the Granger causality test reject capital immobility, the Dumitrescu and Hurlin test concludes that the F-H hypothesis cannot be rejected across all lags. The opposite relationship (investment granger cause savings, panel B of Table 3) strongly rejects the null hypothesis of no causal relationship up to 5 lags for both tests when we examine all countries or the European Union countries. In contrast, the Dumitrescu and Hurlin tet rejects capital immobility for lags 1 and 4 for all the Eurozone countries. Overall, causality tests on panel corroborate to our results from the LRD examination against the validity of the F-H hypothesis, that capital is immobile in the EU and the Eurozone.

\section{Conclusions}

The Maastricht treaty lead of the creation of the EU common market and ultimately the Eurozone, that were both expected to enhance free capital mobility within the country-members. In this paper, following Feldstein and Horioka (1980), we examine the relationship between investment and savings 
using long-run regressions, treating capital mobility as a long-run phenomenon. In doing so, we examine the Long Run Derivative of the aforementioned relationship proposed by Fisher and Seater (1993). Moreover, in order to enhance the robustness of our results, we conduct panel causality tests. Our empirical findings do not provide evidence in favor of the capital immobility hypothesis suggested by Feldstein and Horioka (1980).

Author Contributions: All authors have contributed equally to all parts of the paper.

Conflicts of Interest: The authors declare no conflict of interest.

\section{References}

Andrews, D. W. K. (1991) Heteroskedasticity and Autocorrelation Consistent Covariance Matrix Estimation. Econometrica, 59, 817-858.

Andrews, D. W. K., and J. C. Monohan (1992) An Improved Heteroskedasticity and Autocorrelation Consistent Covariance Matrix Estimator. Econometrica, 60, 953-966.

Apergis N. and Tsoumas Chris (2009) A Survey of the Feldstein-Horioka Puzzle: What Has Been Done and Where We Stand. Research in Economics, 63 (2), 64-76.

Blanchard, O. and Giavazzi, G. (2001) Current account deficits in the Euro area: The end of the Feldstein-Horioka puzzle?. Brookings Papers on Economic Activity, 2, 147-209.

Choudhry T., Kling G. and Jayasekera R. (2014) The Global Financial Crisis and the European Single Market: The end of integration?. Journal of International Money and Finance 49, 191-196.

Dickey D. and Fuller W. (1979) Distribution of the Estimators for Autoregressive Time Series With a Unit Root. Journal of the American Statistical Association, 74 (366), 427-431.

Dumitrescu E.I and C. Hurlin (2012), Testing Granger Causality in Heterogeneous Panel Data Models. Economic Modelling, 29, 1450-1460.

Feldstein, M., Horioka, C. (1980) Domestic saving and international capital flows. Economic Journal, 90 (358), 314-329.

Fisher M. and Seater J. (1993) Long-Run Neutrality and Superneutrality in an ARIMA Framework. American Economic Review, 83, 402-415.

Johnson M. and Lamdin D. (2014) Investment and saving and the euro crisis: A new look at Feldstein-Horioka. Journal of Economics and Business, 76, 101-114.

Katsimi M. and Zoega G. (2016) European Integration and the Feldstein-Horioka Puzzle. Oxford Bulletin of Economics and Statistics, 78 (6), 834-852.

Krugman P., (1991) Has the adjustment process worked? In: Policy Analyses in International Economics 34. Institute for International Economics, Washington.

Kumar, S. and Bhaskara Rao, B. (2011). A time series approach to the Feldstein- Horioka puzzle with panel data from the OECD countries". The World Economy, 34(3), 473-485.

Kwiatkowski, D.; Phillips, P. C. B.; Schmidt, P.; Shin, Y. (1992). "Testing the null hypothesis of stationarity against the alternative of a unit root". Journal of Econometrics. 54 (1-3), 159-178.

Obstfeld M. and Rogoff K. (2001) The Six Major Puzzles in International Macroeconomics : Is There a Common Cause? , In : NBER Macroeconomics Annual 2000, vol. 15. MIT Press, pp.339-3.

Papadimitriou T., P. Gogas and GA Sarantitis (2014) Convergence of European business cycles: A complex networks approach. Computational Economics, 47 (2), 97-119.

Phillips, P. C. B. and Perron, P. (1988) Testing for a Unit Root in Time Series Regression. Biometrika, 75 (2), 335-346.

Schmitz, B. and Von Hagen, J. (2011). "Current account imbalances and financial integration in the euro area“, Journal of International Money and Finance, Vol. 30, 1676-1695.

Schwarz Gideon E. (1978)Estimating the dimension of a model", Annals of Statistics, 6 (2): 461-464,

Serletis A. and Gogas P. (2007) The Feldstein-Horioka Puzzle in an ARIMA Framework. Journal of Economic Studies, 34 (3), 194-210.

Telatar E., Telatar F. and Bolatoglou N. (2007) A regime switching approach to the FeldsteinHorioka puzzle: Evidence from some European countries. Journal of Policy Modeling, 29, 523533. 


\section{$\underline{\text { Appendix }}$}

Table A1: Panel Unit Root results

\begin{tabular}{|c|c|c|c|c|c|c|c|c|}
\hline \multirow[b]{2}{*}{ Method } & \multicolumn{4}{|c|}{ Levels } & \multicolumn{4}{|c|}{ First Differences } \\
\hline & Statistic & $\begin{array}{l}\text { Cross- } \\
\text { sections }\end{array}$ & Obs & $\begin{array}{c}\text { Decisio } \\
\mathrm{n}\end{array}$ & Statistic & $\begin{array}{l}\text { Cross- } \\
\text { sections }\end{array}$ & Obs & Decision \\
\hline \multicolumn{9}{|c|}{ Panel A: Investment } \\
\hline \multicolumn{9}{|c|}{ Null: Unit root (assumes common unit root process) } \\
\hline Levin, Lin \& Chu $t^{*}$ & 0.36 & 16 & 720 & $\mathrm{I}(1)$ & $-25.54 *$ & 16 & 704 & $\mathrm{I}(0)$ \\
\hline \multicolumn{9}{|c|}{ Null: Unit root (assumes individual unit root process) } \\
\hline $\begin{array}{c}\text { Im, Pesaran and Shin } \\
\text { W-stat }\end{array}$ & 1.03 & 16 & 720 & $\mathrm{I}(1)$ & $-24.63^{*}$ & 16 & 704 & $\mathrm{I}(0)$ \\
\hline $\begin{array}{c}\text { ADF - Fisher Chi- } \\
\text { square }\end{array}$ & 15.22 & 16 & 720 & $\mathrm{I}(1)$ & $468.60^{*}$ & 16 & 704 & $\mathrm{I}(0)$ \\
\hline PP - Fisher Chi-square & 14.83 & 16 & 720 & $\mathrm{I}(1)$ & $492.46^{*}$ & 16 & 704 & $\mathrm{I}(0)$ \\
\hline \multicolumn{9}{|c|}{ Panel B: Savings } \\
\hline \multicolumn{9}{|c|}{ Null: Unit root (assumes common unit root process) } \\
\hline Levin, Lin \& Chu t* & -1.54 & 16 & 720 & $\mathrm{I}(1)$ & $-19.90^{*}$ & 16 & 704 & $\mathrm{I}(0)$ \\
\hline \multicolumn{9}{|c|}{ Null: Unit root (assumes individual unit root process) } \\
\hline $\begin{array}{c}\text { Im, Pesaran and Shin } \\
\text { W-stat }\end{array}$ & -0.78 & 16 & 720 & $\mathrm{I}(1)$ & $-18.61 *$ & 16 & 704 & $\mathrm{I}(0)$ \\
\hline $\begin{array}{c}\text { ADF - Fisher Chi- } \\
\text { square }\end{array}$ & 27.25 & 16 & 720 & $\mathrm{I}(1)$ & $336.73 *$ & 16 & 704 & $\mathrm{I}(0)$ \\
\hline PP - Fisher Chi-square & 29.21 & 16 & 720 & $\mathrm{I}(1)$ & $330.99 *$ & 16 & 704 & $\mathrm{I}(0)$ \\
\hline
\end{tabular}

Note: Probabilities for Fisher tests are computed using an asymptotic Chi square distribution. All other tests assume asymptotic normality. 8 denotes rejection of the null at the $5 \%$ level of significance. The lag order for all tests is selected according to the minimum SIC. We use the Bartlett kernel for all tests, while the bandwidth selection is based on the procedure of Newey-West.

Table A2: Panel Cointegration results

\begin{tabular}{l|c|c|c|c|c|c}
\hline & \multicolumn{3}{|c|}{ Within-dimension } & \multicolumn{2}{c}{ Between-dimension } \\
\cline { 2 - 7 } & Statistic & Prob. & $\begin{array}{l}\text { Weighted } \\
\text { Statistic }\end{array}$ & Prob. & $\begin{array}{l}\text { Statisti } \\
\text { c }\end{array}$ & Prob. \\
\cline { 2 - 7 } Panel v-Statistic & 6.02 & 0.00 & 6.02 & 0.00 & & \\
Panel rho-Statistic & -7.43 & 0.00 & -7.43 & 0.00 & -4.91 & 0.00 \\
Panel PP-Statistic & -5.34 & 0.00 & -5.34 & 0.00 & -4.87 & 0.00 \\
Panel ADF-Statistic & -4.98 & 0.00 & -4.98 & 0.00 & -4.43 & 0.00 \\
\hline \hline
\end{tabular}

Note: Null hypothesis: no cointegration. Trend automatic lag length selection based on SIC up to 10 lags. Deterministic intercept. Newey-West automatic bandwidth selection and Bartlett kernel. 